\title{
The Rohingya Crisis: Demand for international pressure for a change in Myanmar
}

\author{
Hariati Ibrahim @ Musa, Namirah Mohd Akahsah \\ Centre of Foundation Studies, \\ Universiti Teknologi MARA, Dengkil, Selangor, Malaysia \\ hariati80@uitm.edu.my, namirah9532@uitm.edu.my \\ +60 192264142
}

\begin{abstract}
The notorious violation of the human rights of ethnics in Myanmar has attracted the attention of the international community. Such abuse is threatening the South East Asia peace and security. This article unravels the legal and historical nexus between the Rohingya and Myanmar, supporting their claim for the rights of citizenship. This article suggests a tripartite model of which involves cooperation between the government of Myanmar, ASEAN and, the United Nations. The collective efforts from these three parties are vital to ensure a change in the crisis.
\end{abstract}

Keywords: ASEAN, Human rights, Rohingya, United Nations

eISSN: 2398-4287 @ 2020. The Authors. Published for AMER ABRA cE-Bs by e-International Publishing House, Ltd., UK. This is an open access article under the CC BYNC-ND license (http://creativecommons.org/licenses/by-nc-nd/4.0). Peer-review under responsibility of AMER (Association of Malaysian Environment-Behaviour Researchers), ABRA (Association of Behavioural Researchers on Asians) and cE-Bs (Centre for Environment-Behaviour Studies), Faculty of Architecture, Planning \& Surveying, Universiti Teknologi MARA, Malaysia.

DOI: https://doi.org/10.21834/ebpj.v5iSI1.2302

\subsection{Introduction}

The protection of human rights has been at the heart of all sovereign states, including Myanmar. However, Myanmar human rights profile and record have failed to meet the standard expectation with the notorious violation of human rights of ethnics in Myanmar, including the Rohingya. Bangladesh, Thailand and, Malaysia in, particular, receive the most number of Rohingya migrants who have become an unwelcome liability to these countries. Hence, the violation of human rights of the Rohingya is not only risking the Myanmar political transition but also threatening South East Asia peace and security. Despite mounting international pressure calling for immediate action, the government of Myanmar has denied responsibility and blames the insurgents for the widespread atrocities. This article unravels the legal and historical nexus between the Rohingya and Myanmar, thus, supporting their claim for the rights of citizenship. Establishing the legal and historical relationship between the Rohingya and Myanmar is essential to correct the misconception that the Rohingya are not of Myanmar origin, and as such, be excluded from the list of recognised ethnics. Based on the premise that the government of Myanmar is responsible for protecting every individual in its territory, this article suggests a tripartite model as a solution to the crisis. The tripartite model involves an active role of three main stakeholders, the government of Myanmar, ASEAN and, the UN, who represents the international community. The collective efforts from these three parties are vital to ensure a change in the current situation of the crisis. This research adopts a qualitative research method whereby analysis is made by referring to literature and the relevant international law on the issue.

\subsection{Literature Review}

The issue of the Rohingya, a community that faces continued and extreme violations of human rights by the ruling government, has attracted the concern of the world. As of November 2017, the United Nations Refugee Agency (UNHCR) estimated that 615,500 
Rohingya had fled to Bangladesh (UNHCR, 2017) while Al Jazeera reported that an estimation of 150,000 left for Malaysia (Al Jazeera, 2017). Social and legal discrimination (ECHO, 2017) are among the reasons for them to flee from Myanmar. 'Rohingya' is a controversial terminology in Myanmar. The etymology of the word Rohingya is divided into two parts. The first part is by tracing the etymology to Arab. The term Rohingya is the Arabic word for 'Rahm' meaning mercy. Secondly, by determining the etymology to Pakistan or Afghanistan, the 'Roh' in Rohingya means 'mountain' (Ahmad, 2013). Jilani (1999) opines that the name Rohingya is derived from 'Rohan,' 'Roham' or 'Roshan' which were old names of the capital of the ancient Arakan Kingdom, Mrauk-U.

The right to self-identity is among fundamental human rights, yet the Rohingyas are being denied from such rights. The Myanmar government officially refutes the Rohingya identity, as President Thein Sein has said, "There are no Rohingya among the races", of Myanmar (APHR, 2015). The government and the people of Myanmar officially deny the term Rohingya and identify them as descendants of illegal Bengalis who were brought into Myanmar by the British therefore, since then, they have been living in Myanmar illegally (Kipgen, 2013). The Rohingya is one of the world's persecuted minority (UN, 2013: (UNHCR, 2015) suffering slow-burning genocide (APHR, 2015) (Zarni, 2014), ethnic cleansing (Ibrahim, 2016) and crimes against humanity (Wagley, 2014). The human rights violation against the Rohingya is so systematic and widespread that it may constitute crimes against humanity. (Quintana, 2014) In a more recent development, the UN asserted that the government's discrimination is a "textbook example of ethnic cleansing." (United Nations, 2017) After visiting Cox Bazar, the UN Secretary-General, António Guterres illustrated the atrocities against the Rohingya as "the world's fastest developing refugee emergency and a humanitarian and human rights nightmare" (UN News Centre, 2017). In Malaysia, The People's Tribunal on Myanmar decides that the government of Myanmar is guilty of genocide, war crimes, and crimes against humanity (Permanent Tribunal, 2017). Human rights organisations such as Amnesty International, Human Rights Watch, Fortify Rights, United to End Genocide, etcetera have produced detailed reports documenting appalling human rights violations against the Rohingya (APHR, 2015). The Independent International Fact Findings Mission on Myanmar concluded a visit to Bangladesh and had interviewed victims who narrated the killings, gang-rape, arson, brutal beatings and various types of violence committed by Myanmar security forces. (OHCR, 2017)

On 30th December 1949, Myanmar (then Burma) has ratified Convention on the Prevention and Punishment of the Crime of Genocide, which establishes responsibility on the government to prevent and punish actions of genocide in war and peacetime. Hence, it becomes an obligation of the government of Myanmar to comply and apply international regulations. Thus, Myanmar has failed in its responsibility by committing an unlawful act. Considering the government's attitude towards the Rohingya, it is inevitable that change and reforms need to be initiated from within Myanmar. Hence, this article suggests that there is an essential collective responsibility that falls on ASEAN and the international community ethnoto take immediate action to alleviate the sufferings of the Rohingya.

\subsection{Methodology}

The research adopts a qualitative research method in discussing the reality and ways to solve the Rohingya crisis. Historical evidence of the long existence of Rohingya in Arakan is dated back to 1799, whereby Francis Buchanan used the term 'Rooinga' (Rohingya) referring to Muhammedans, the Muslim settlers in Arakan State (Buchanan, 1799). This finding is supported by Gordon H. Luce, stating that 'Rohinjas', a devout and scholarly minded Muslims as part of the principal inhabitants of Mayu river region (Mayu is a river in Arakan State) (Luce, 1985). Another piece of evidence to corroborate the earlier proofs is in an early ethnolinguistic survey published by a British East India Company employee in 1795, the Rohingya were grouped with other ethnic groups of the Islamic faith (Ibrahim, 2016). During the administration of $\mathrm{U} \mathrm{Nu}$ (who took the reign in 1962) and the early years of Ne Win's administration (who served as Prime Minister in 1958), there were government-printed books, official radio broadcast, government-issued licenses and public statements recognising the existence of Rohingya (Mann, 2014). In modern recorded history, the Muslims from Arakan were among those who had voted in the first Constituent Assembly election in 1947. In the 1990 election, they were permitted to vote and stand as candidates. Mr. Abu Taher, a notable Rohingya rights advocate, had qualified as a candidate in both the 1990 and 2010 elections. (Burmese Rohingya Organisation UK, 2015). History cannot be altered or erased. Therefore, it is a clear fact that the Rohingya community had existed since the early history of the nation and were allowed to contest in the state elections. These shreds of evidence proved a legal and historical nexus between the Rohingya and Arakan State. Conclusively, the Rohingya used to be part of Myanmar before the enactment of the discriminatory Burma Citizenship Law 1982.

\subsection{Proposed Solutions to the Rohingya Crisis}

\subsection{Allow access to the affected areas}

The government of Myanmar must do all means necessary to end the violence immediately and to provide security to everyone within its territory regardless of ethnicity, creed and skin colour. Despite the government stern policies denying the right of citizenship, Rohingya are living within the territorial jurisdiction of Myanmar, thus are entitled to be protected from violence. The Rohingya should be allowed safe and voluntary return to Arakan State. One of the most immediate and pertinents action is to allow unfettered access to human rights monitors, international non-governmental organisations, and independent journalists to provide the much-needed humanitarian aids to those desperately in need and to assess the situation in the conflict areas. The government wants exclusive control in giving out the humanitarian response; however, human rights group fear that the aid might not reach the right hands (Amnesty International, 2017). Immediate access is vital to meet at least two objectives which are to deliver humanitarian assistance, and secondly to assess the real 
situation in the areas of conflict. If the government is sincere in its claim that there is no ethnic oppression, it should be transparent and prove to the international community through its willingness to build cooperation with international bodies.

\subsection{Review the 1982 Burma Citizenship Law}

The right of citizenship is of paramount importance as it leads to the realisation of other fundamental rights. Everyone has the right to nationality and, no one shall be arbitrarily deprived of the power. (Article 15 of Universal Declaration of Human Rights).Article 5 of the Convention on the Elimination of all Forms of Racial Discrimination provides the prohibition and elimination of racial discrimination in all its forms and to guarantee the right of everyone, without distinction as to race, colour, or national or ethnic origin. Myanmar ratified Convention on the Rights of Child whereby Article 7 gives children the right to be registered right after birth, thus attain the nationality of Myanmar. The government of Myanmar in 1982 passed the Burma Citizenship law, excluding the Rohingya from the list of the recognised nationals, therefore it violates these provisions. (Abdelkader, 2013) According to Southwick (2014),Fjus the amendment is the 'most protracted case of statelessness.' The 1982 law categorises citizenship into three types namely;

(i) Full citizenship - The 1982 Law recognises Kachin, Kayah, Karen, Chin, Burman, Mon, Rakhine or Shan and ethnic groups as have settled in any of the territories included within the State as their permanent home from a period anterior to 1185 B.E., 1823 A.D. as Burma citizens (Article. 3(1)).

(ii) Associate citizenship - A person is eligible for associate citizenship if he or she qualified for citizenship and had applied for citizenship under previous law in 1948.

(iii) Naturalised citizenship - To be a naturalised citizen, a person must provide conclusive evidence of entry into Burma before 1948. In addition to these two qualifications, there are other requirements provided under sections 44, 1982. The strict requirements in the Act make it almost impossible for the majority of the Rohingya to provide evidence to claim for citizenship despite them having lived in Myanmar for centuries. Therefore, since the passing of the Act, the Rohingyas are considered as 'foreigners' in Myanmar. The 1982 Act is used as a justification for systematic arbitrary mistreatment against them (Kaewjullakarn \& Kovudhikulrungsri, 2015).

The 1982 Burma Citizenship Law must be reviewed to meet the international law standard on the issue of nationality. The law discriminates against the Rohingya and has made them a "devastating case of statelessness" (Razali, Nordin \& Duraisingam, 2015). Kipgen (2013) argues that the crux of the problem is the lack of political integration; hence one of the vital ways to solve the problem includes the consideration of Rohingya's right to citizenship. Various Inter-Governmental Institutions and International nonGovernmental Institutions such as the UN, Human Rights Watch, (HRW) Physicians for Human Rights (PHR), Amnesty International, Arakan Project and, etcetera urge the government to repeal the discriminatory 1982 Law. A clear message delivered by the UN Special Rapporteur Tomas Ojea Quintana on $16^{\text {th }}$ February 2013 declared that the Burma Citizenship Law should be applied in a nondiscriminatory manner to enable people with a just claim to citizenship, to claim it on an equal basis with others, including those from the Rohingya community. (Quintana, 2013). It is an established rule of international customary law that someone born within a territory of a State acquires that State's nationality. Hence, amending the constitution and allowing citizenship for the Rohingya born in Arakan is consistent with international standards.

Malaysia had faced the same problem upon its independence. The Chinese and Indian immigrants who were brought into Malaysia by the British were to return to their homeland. However, still some chose to remain and regard Tanah Melayu (Malaysia) as their new homeland. When Malaysia was struggling for its independence, the Malay Rulers decided to accept these immigrants as part of Malaysian society and give them citizenship despite although most of them had settled in the country for merely three generations or less. Despite different religions and cultures, the three major races in Malaysia namely, Malay, Chinese, an Indian can live in harmony within one society making Malaysia an exemplary country on ethnic relations (Iqbal, 2016). The Rohingya were historically recognised as residents of Arakan as early as the $8^{\text {th }}$ century. Therefore they must be accepted and given the rights that are due to them. Thus, it is incumbent upon the government of Myanmar to amend its discriminatory and prejudiced laws against ethnic groups.

In the long run, the Rohingya crisis will cause collateral damage to the neighbouring countries and threatens regional peace and security. It is, therefore in, every government interest to adopt comprehensive frameworks to manage the issue. Myanmar is currently undergoing a political transition and is moving towards a full pledge democracy. The growing humanitarian crisis will hamper the process of democracy in Myanmar and tarnish the government's reputation. The government's effort of trying to sweep the abuse under the carpet is making them less credible.

\subsection{Humanitarian intervention by the UN and ASEAN}

Humanitarian intervention on the Rohingya crisis by the UN and ASEAN is needed as it is a collective global responsibility for them to interfere with this issue. The dimension of the crisis is so broad that it threatens the stability and security of the South East Asian region. Hence, ASEAN, with its motto "One Vision, One Identity, One Community," must act accordingly. ASEAN is in the perfect position to act critically on Myanmar but, ASEAN continues to refer to a non-interference principle or the ASEAN Way in dealing with the issue. The glaring omission of the Rohingya crisis from the discussion in the 30th ASEAN Summit in Manila on $26^{\text {th }}$ April 2017 is a consequence of the observation of the non-interference principle. Two factors that shaped ASEAN's adherence to the non-interference principles are (i) the experience during the colonial rule, the Cold war and the threat of communism which has led the South-east Asian states to perceive the State-sovereignty as an essential element to sustain and to preserve domestic stability, (ii) defending internal stability as a security measure is considered to be gravely important. The 'non-interference' principle, however is not to be construed literally as noninvolvement at all. ASEAN had, in a few situations, intervened in the domestic affairs of a few member states (Nguyen, n.d). The conflict in Rohingya has become an unwelcome strain on ASEAN. Jones (2012) and also in (2009) argues that ASEAN has in some of its conduct in the past show some inconsistency in the application of the norm of non-interference. It is argued that non-interference can 
no longer be used as an excuse for inaction on Myanmar. The ASEAN policy of non-interference must be reassessed to provide for a safe and stable region. Myanmar's treatment of the Rohingya has continually undermined ASEAN's credibility. Myanmar membership in ASEAN in 1999, albeit late (late entrance due to political instability), is an indication of its commitment to transformation. Thus, the responsibility needs to be materialised in the Rohingya issue. The former Malaysian Prime Minister commented that the denial of people's rights in Myanmar is a 'shame and gross injustice.' (Mohamad, 2014).

The primary purpose of the ASEAN Intergovernmental Commission on Human Rights (AICHR) is to protect and promote human rights of the ASEAN community (AICHR TOR, 2009). It is to be applied based on the core of ASEAN principles, consensus, consultative and, non-intervention (Ariffin, 2016). AICHR is expected to provide tangible steps for the resolution of cases on human rights violations in Myanmar. However, the existence of AICHR has been unable to enforce the human rights violations in Myanmar as the body lack enforcement competency to impose accountability upon the transgressor of human rights in ASEAN. Enough with blueprints and beautiful statements, ASEAN must act proactively in exerting pressure on Myanmar to handle the issue according to the e of international law. The concerted efforts would be more productive with the UN strengthening its ties with the ASEAN and civil societies by sharing information and assessment about Myanmar. There must be an established partnership between the UN and ASEAN human right machinery to work out with the government to build-up the State capacity and provide humanitarian assistance.

Since the outbreak of violence in 2012, the government of Myanmar has failed to take adequate measures to protect the Rohingya. The UN must urge the government to stop the violence immediately, establish the rule of law and respect for human dignity. Respect for the rule of law requires compliance with the principle of equality before the law, equal protection of the law and, the prohibition of discrimination on any ground (Pillay, 2012). The ongoing brutality imposes serious repercussions to the whole Myanmar populations as well as the South East Asian community especially, Bangladesh. The UN has been pursuing engagement efforts in Myanmar for years, but it is proven insufficient to protect the Rohingya. The UN is supposed to protect humankind from oppression and violation. Hence, it has to do more than just concluding a resolution condemning the violation of human rights.

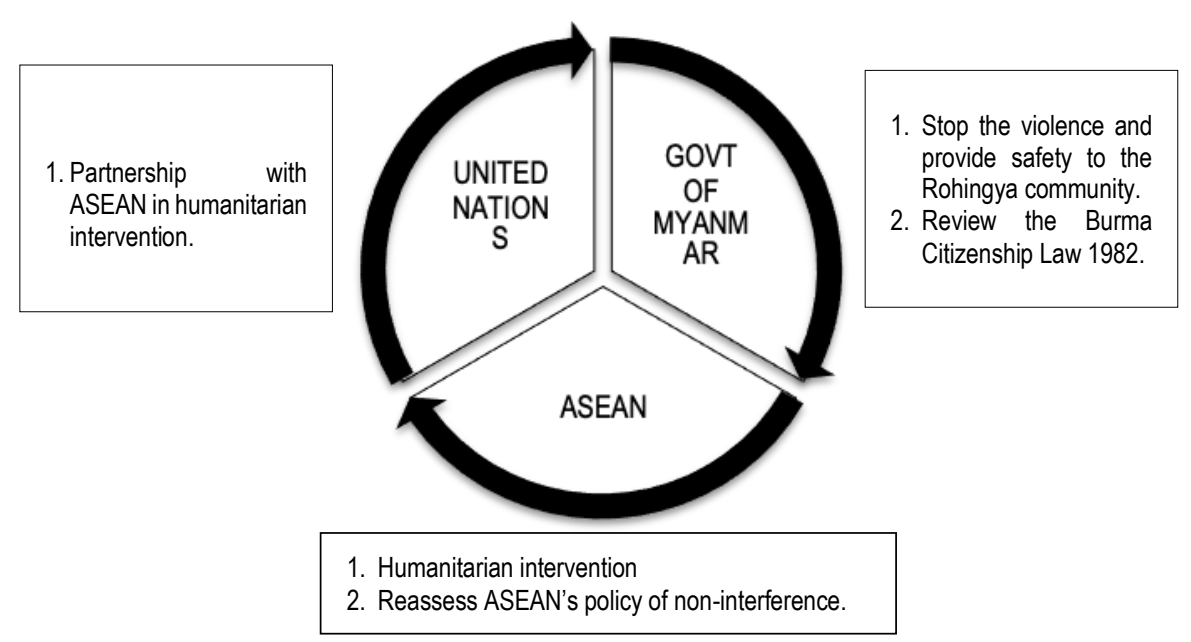

Fig 1: The Tripartite Model of Solution to Rohingya Crisis

\subsection{Conclusion \& Recommendations}

Since the enactment of the Burma Citizenship Law in 1982, the Rohingya faces systematic persecution, marginalised from the Burmese society, and is denied various rights that are due to them. Myanmar is undergoing a political transition, dreaming of building a democratic and peaceful country for the people. However, reality shows that the government is failing hard in delivering its promise. Myanmar is lack of a matured political leadership and giving the fragile state politics in Myanmar, international intervention is essential. The government of Myanmar has failed to protect the Rohingya from genocide, ethnic cleansing, and crimes against humanity. The tripartite model of solution emphasises on the collective responsibility of the three main stakeholders which are, the government of Myanmar, ASEAN, and the UN. It is clear that the government of Myanmar is the predominant factor in the state's political system, but, still, considering the current government policies and treatment towards the Rohingya, it is unlikely that change is advancing soon. It is, therefore crucial, for international and regional organisations like the UN and ASEAN as well as the international community to assert its power of influence on Myanmar. The government must review the discriminatory Burma Citizenship Law 1982, allow access to the conflict area and establish the rule of law. The UN, ASEAN, OIC, and the international community must do all the necessary to end these crimes and pressure the government to act immediately. Thus, it is of utmost importance that these arrays of initiatives must be inclusive of all the stakeholders - to pose a clear-cut message from the international community to the government of Myanmar, that abusive treatment to any human being is not right. 


\section{Acknowledgments}

The authors gratefully acknowledge the financial assistance of Centre of Foundation Studies, Universiti Teknologi MARA (UiTM), Cawangan Selangor, Kampus Dengkil for making it possible for us to pursue this research.

\section{References}

Abdelkader, E. (2013). The Rohingya Muslims in Myanmar: Past, present, and future. 15 Or. Rev. Int'I L. 393, 412. HeinOline.

Arifin, N. A. (2016). ASEAN's role in mitigating the risks of Rohingya radicalization. Jurnal Hubungan Internasional, (1), 67-80. Retrieved from http://journal.unair.ac.id/download-fullpapers-jhic1604eb0f3full.pdf

Burma Citizenship Law 1982. Retrieved from www.ilo.org/dyn/natlex/docs/ELECTRONIC/87413/99608/.../MMR87413.pdf

Chong, E. P. S. (2016). The role of non-domestic factors in the perpetuation of Rohingya crisis. Yonsei Journal of International Studies. 128-147. Retrieved from http://theyonseijournal.com/wp-content/uploads/2017/06/17SS_YJIS_Rohingya.pdf

Golliard, M.M. (2013). Economic sanction: Embargo on stage. Theory and Empirical Evidence. University of Tampere.

Ibrahim, A. (2016). The Rohingyas: Inside Myanmar's hidden genocide. UK: Hurst \& Co. (Publishers) Ltd.

Iqbal, U. (2016). Ethnic relations in Malaysia: Harmony and conflict. Arabian Journal Business Management Review, 6, 208. DOI:10.4172/2223-5833.1000208

Jilani, A.F.K. (1999). The Rohingyas of Arakan: Their quest for justice. N.p.: Ahmed Jilani (published by).

Jones, L. (2012). ASEAN, Sovereignty and intervention in South East Asia. UK: Palgrave Macmillan.

Jones, L. (January 20, 2014). ASEAN and the Norm of non-interference in Southeast Asia: A Quest for social order. Retrieved from https://www.nuffield.ox.ac.uk/politics/Papers/2009/Jones.March2009.pdf

Kaewjullakarn, S., \& Kovudhikulrungsri, L. (2015). What legal measures should ASEAN apply to help the Rohingya?. South East Asia Journal of Contemporary Business, Economics, and Law, 6 (4), 6-13.

Kipgen, N. (2013). Addressing the Rohingya problem. Journal of African \& Asian Studies, (2).

Luce, G.H. (1985). Phases of Pre-pagan Burma: Languages and history. New York: Oxford University Press.

Mann, Z. (2014). Monk conference backs Bills to restrict interfaith marriage, Rohingya voting. Retrieved from http://www.irawady.org/burma/monl-conference-backs-billsrestrict-interfaith-marriage-rohingya-voting-html

n.a. (2011). Recommendations Relevant to Statelessness made during the First Cycle of the Universal Periodic Review (2008-2011), UNHCR.

n.a. (2015). "Myanmar Global Appeal 2015 Update", UNHCR. Retrieved from http://www.unhcr.org/5461e60bc.html

n.a. (2016). Establishment of the advisory commission on Rakhine state. Retrieved from http://www.statecounsellor.gov.mm/en/node/228

n.a. (April 25, 2017). Council decision (CFSP) 2017/734 of 25 April 2017 amending decision 2013/184/cfsp concerning restrictive measures against Myanmar/Burma. Retrieved from http://eur-lex.europa.eu/eli/dec/2017/734/oj

n.a. (April, 2005). "The Rohingya crisis and the risk of atrocities in Myanmar: An ASEAN challenge and call to action." ASEAN Parliamentarians for Human Rights n.a. (February 3, 2017). Devastating cruelty against Rohingya children, women and men detailed in UN human rights report. OHCR. Retrieved from http://www.ohchr.org/EN/NewsEvents/Pages/DisplayNews.aspx?NewsID=21142

n.a. (November, 2015). No Hope for Rohingya from Burma Election. London: Burmese Rohingya Organization UK. Retrieved from http://burmacampaign.org.uk/media/BROUK-Rohingya-Election-Briefing.pdf

n.a. (October 27, 2017). Experts of the independent international fact finding mission on Myanmar conclude visit to Bangladesh. United Nation Human Rights Office of the High Commissioner. Retrieved from http://www.ohchr.org/EN/NewsEvents/Pages/DisplayNews.aspx?NewsID=22320\&LangID=E

n.a. (October 7, 2016). "Burma (Myanmar) Sanctions - Sanctions Program ended as of 10/7/2016". U.S Department of Treasury. Retrieved from https://www.treasury.gov/resource-center/sanctions/Programs/pages/burma.aspx

n.a. (October, 2017). "ECHO Factsheet - The Rohingya Crisis." European Commission Civil Protection and Humanitarian Aid Operation. Retrieved from http://ec.europa.eu/echo/files/aid/countries/factsheets/rohingya_en.pdf

n.a. (September 06, 2017). "Persecution path: Following Myanmmar's fleeing Rohingya". Aljazeera. Retrieved from http://www.aljazeera.com/indepth/interactive/2017/03/persecution-path-myanmar-fleeing-rohingya-170314125333337.html

n.a. (September 11, 2017). "UN human rights chief points to 'textbook example of ethnic cleansing' in Myanmar". UN News Centre. Retrieved from http://www.un.org/apps/news/story.asp?NewsID=57490\#.WeReZWiCzIV

n.a. (September 4, 2017). "Myanmar: Restrictions on international aid putting thousands at risk". Amnesty International. Retrieved from https://www.amnesty.org/en/latest/news/2017/09 
Nguyec, D. T. (n.d.) "The future evolvement of the principle of non-interference?" Diplomatic Academic of Vietnam.

Permanent People's Tribunal: State crimes allegedly committed in Myanmar against the Rohingyas, Kachins and other groups. University of Malaya, Faculty of Law, 1822 September 2017, Kuala Lumpur, Malaysia. Retrieved from http:///www.tribunalepermanentedeipopoli.fondazionebasso.it

Pillay, N. (2012). Rights, High Commissioner for Human Rights UN General Assembly. https://news.un.org/en/story/2012/07/416532-myanmar-un-official-concernedover-rights-violations-rakhine-state

Quintana, T. O. (2013). Situations of human rights situations in Myanmar Note by the Secretary General A/68/397. General Assembly.

Razali, R. M., Nordin, R., \& Duraisingham, T. J. (2015). Migration and statelessness: Turning the spotlight on Malaysia. Pertanika Journal of Social Science \& Humanities, 23, 9-36.

Southwick, G. K. (2014) Myanmar's Democratic Transition Peril or Promise for the Stateless Rohingya? Tilburg Law Review.19, 261-275

UNHCR. (2017). 'Rohingya emergency'. Retrieved from http://www.unhcr.org/en-my/rohingya-emergency.html

United Nations Secretary-General. (September, 28 2017). Secretary-General's remarks at open debate of the Security Council on Myanmar. Retrieved from https://www.un.org/sg/en/content/sg/statement/2017-09-28

Wagley, R. (2014). The Quiet audience: U.S. responsibility to call for an International investigation into crimes against Muslims in Burma. Emory International Law Review, 62. HeinOnline.

Wulandari, I, Oktavika, D.A. \& Festiani. S. (September 19, 2012). Mahathir calls the world's solidarity for Rohingya. Republika Online. Retrieved from http://en.republika.co.id/berita/en/islam-in-archipelago/12/09/19/malumw-mahathir-calls-the-worlds-solidarity-for-rohingya

Zarni, M. (2013-2014). The Slow-Burning Genocide of Myanmar's Rohingya. Pacific Rim Law \& Policy Journal, 23(3), 683-754 